\title{
HEALTH EFFICIENCY MEASUREMENT IN TURKEY BY USING DATA ENVELOPMENT ANALYSIS: A SYSTEMATIC REVIEW
}

\section{Gözde YEŞiLAYDIN ${ }^{1}$}

\begin{abstract}
Objective: This paper provides a systematic literature review that compiles studies on health efficiency analysis using data envelopment analysis (DEA). This study aimed to compare different researches on efficiency analysis in healthcare in Turkey. Also it was aimed to determine which decision making unit (DMU), which input and output variables were used frequently in these researches.
\end{abstract}

Method: Data envelopment analysis (DEA) is one of the most commonly used efficiency measurement methods in health care. In DEA, selection of input and output variables is very important issue for assessing efficiencies of decision making units. Because this selection varies from researcher to researcher, so it is a subjective issue. In this study, studies conducted by using DEA in health care between 2010 and October 2017 have been examined.

Results: For the selection of studies conducted using DEA in health care, some eliminations were made according to the criteria determined by the author. According to the results, In Turkey, DEA was frequently used in 2010. Researches are published as only articles in 2017.The greatest diversity in terms of types of the studies is in 2010. More than half of the 52 studies (approx. $62 \%$ ) selected hospital as a decision-making unit.The most frequently used input variable was identified as "the number of physicians" and output variable was "the number of surgical operations".

Conclusion: It is thought that this study will guide for researchers, academics and health economics to evaluate the efficiency of health care using DEA in terms of the selection of input and output variables which is the most important stage of DEA applications. Also, with this study, it has tried to create awareness for policymakers and health managers toimprove the efficiency of their organizations.

Keywords: Data envelopment analysis, efficiency, healthcare, hospital, systematic review

1 Yrd.Doç.Dr., Eskişehir Osmangazi Üniversitesi Sağlık Bilimleri Fakültesi Sağlık Yönetimi Bölümü Eskişehir, gyesilaydin@ogu.edu.tr 


\section{Veri Zarflama Analizi İle Türkiye'de Sağlik Etkinliğinin Ölçülmesi: Sistematik Bir Analiz}

\section{Özet}

Amaç: Bu çalışma, veri zarflama analizi yöntemikullanarak sağlık alanında etkinlik analizi yapan çalışmaların derlendiği bir sistematik analiz çalışmasıdır. Çalışmada Türkiye'de sağlık alanında etkinlik analizi üzerine yapılan farklı araştırmaların karşılaştırııması amaçlanmıştır. Ayrıca bu çalışmalarda hangi karar verme birimlerinin; sağlıkla ilişkili olan hangi girdi ve çıktı değişkenlerinin ne sıklıkla kullanıldığı belirlenmeye çalışımıştır.

Method: Veri zarflama analizi (VZA), sağlık alanında yaygın olarak kullanılan etkinlik ölçme yöntemlerinden biridir. Veri zarflama analizinde karar verme birimlerinin (KVB) etkinliklerinin değerlendirilmesi için girdi ve çıktı değişkenlerinin seçimi oldukça önemlidir. Çünkü girdi ve çıktı değişkenlerinin seçimi, araştırmacıdan araştırmacıya değişmektedir, bu nedenle seçim özneldir. Çalışma kapsamında 2010-Ekim2017 yılları arasında sağlık alanında veri zarflama analizi kullanan çalışmalar incelenmiştir.

Bulgular: Sağlık hizmetlerinde veri zarflama analizi yöntemi kullanılarak yapılan çalışmaların seçimi için, yazar tarafından belirlenen kriterlere göre bazı elemeler yapılmıştır. Çalışmanın sonuçlarına göre, Türkiye'de veri zarflama analizi sıklıkla 2010 yılında kullanılmıştır. 2017 yılında yapılan çalışmaların hepsi makale olarak yayınlanmışı̧ı. Yayın türüne göre en fazla çeşitlilik 2010 yılına aittir. İncelenen 52 çalışmanın yarısından fazlası (yaklaşık \%62'si) karar verme birimi olarak hastaneleri seçmiştir. Çalışmalarda en sık kullanılan girdi değişkeni "hekim sayısı"; çıktı değişkeni ise "ameliyat sayısı" dır.

Sonuç: Bu çalışmanın, veri zarflama analizi uygulamalarının en önemli aşaması olan girdi ve çıktı değişkenlerinin seçimi açısından veri zarflama analizi yöntemini kullanarak sağlık alanında etkinlik değerlendirmek isteyen araştırmacılara, akademisyenlere ve sağlık ekonomisi çalışacaklara yol göstereceği düşünülmektedir. Ayrıca bu çalışma ile politika yapıcılar ve sağlık yöneticileri için örgütlerinin etkinliğini iyileştirmek adına farkındalık yaratı Imayaçalışımıştır.

Anahtar Kelimeler: Veri zarflama analizi, etkinlik, sağlık, hastane, sistematik analiz

\section{Introduction}

Health services, which are one of the development indicators of the societies, are important for all countries. Due to the acceleration of globalization, the advancement of technology, the increasing 
awareness of healthcare users and the rising the costs of health services, healthcare providers should be more careful in providing healthcare services and evaluate the efficiencies of their services.

Today, the needs are endless, but the resources needed to meet them are limited. For this reason, one of the most important elements of competing in a changing and developing world is to use available resources effectively and efficiently. It is necessary to measure whether resources are being used efficiently, to determine at what level they are used efficiently, to make comparisons between countries or businesses that operate in the same sector or produce similar products / services. For this purpose, efficiency analysis is one of the commonly used methods by researchers. ${ }^{1-4}$

With efficiency measurement, it is possible to determine the current situation, weaknesses and strengths, to compare with relative activities of similar economic units, to determine the differencesand to make further analyzes on these differences, to identify priorities to be used in decision making, to set policies, realistic goals and new strategies for improving the efficiency. ${ }^{5,6} \mathrm{In}$ this way, information that can be a guide for businesses, administrators and policy makers can be obtained.

One of the major problems in terms of management of enterprises is the determination of the relative efficiencies of decisionmaking units that produce similar outputs with similar inputs ${ }^{7}$. This challenge is also the case for health care institutions. Moreno et al. (1999) stated that hospital efficiency can reach an adequate level if hospital administrations distribute resources appropriately. ${ }^{8}$

Despite the different techniques used for efficiency measurement, DEA has ingreasingly been widely used method. DEA is a linear programming based, nonparametric method used to measure relative efficiencies of multiple similar decision making units and to produce similar outputs using similar inputs. ${ }^{9-13}$ In this method, the "best" decision-making unit that produces the most output composition by using the least input composition is determined. This "best" decision-making unit sets the efficient frontier. This is considered as a "reference" and the efficiency of the ineffective decision-making unit is measured radially according to this reference point. The efficiency of other decision-making units are determined by proportionally measuring their distance from this frontier. ${ }^{14}$, ${ }^{15}$ Therefore, the DEA compares each decision-making unit with only 
the "best". ${ }^{16,}{ }^{17}$ In the DEA, each decision-making unit is evaluated separately and the efficiency of them is determined by whether it is above or below the efficient frontier ${ }^{17}$.

Determination of inputs and outputs is the most important issue for researchers to conduct DEA application. In the course of this thought, in this study, it was aimed to determine which decision making unit, which input and output variables are used frequently to evaluation of health efficiencies. So,this study will guide for researchers and academics to evaluate the efficiency of health care using DEA in terms of the selection of input and output variables which is the most important stage of DEA applications.

\section{Data Envelopment Analysis In Health Sector}

Data envelopment analysis is a method that is frequently preferred and widely used in health sector ${ }^{18,} 19$. While some of the studies usingDEA in health sector have been published as research articles; some studies have been designed as systematic review articles.For example, Hollingsworth et al. (1999) counted a total of ninety oneDEA studies in health careby $1997 .{ }^{19}$ O'Neill et al. (2008) examined seventy nine studies conducted between 1984 and 2004 to evaluate the efficiencies of hospitals using DEA in which twelve countries were represented. ${ }^{20}$ In the study, the input and output variables are grouped and detailed information about them is presented.Pelone et al. (2015) compiled studies that measure the efficiency of institutions that provide primary health care using DEA. ${ }^{21}$ As a result of certain criteria, a total of 39 studies have been reviewed. In theirstudy, some features such as countries where the studies are conducted, the types and numbers of decision-making units and the models are mentioned. For example, when looking at the graph of changes in numbers of studies by years, it seems that maximum number of studies conducted using data envelopment analysis in primary health care services have been done between 2011-2014. Ayrıçay and Özçalıcı (2014) examined more than a hundred articles using data envelopment analysis published in Turkey between 1997 and $2012 .{ }^{22}$ They found that DEA was used to evaluate the efficiencies of health and financial institutions at the most.

The selection of inputs and outputs is a subjective issue because there is not a definite rule for the selection of them. ${ }^{23}$ Selected inputs must include the resources and selected outputs must reflect the 
activities of decision-making units. ${ }^{11,}{ }^{13}$ The inputs and outputs which do not represent the process well in the analysis will cause the efficiency measurements to be unhealthy. ${ }^{15} \mathrm{On}$ the other hand, ignoring an important variable can change the outcome of the efficiency and cause to decrease the efficiency scores of the decision-making unit that actually uses this variable effectively. ${ }^{24} \mathrm{For}$ this reason, a list of all variables considered to be necessary and influenced by the process of selection of input and output should be extracted. But in addition to this, the number of inputs and outputs should be kept at a reasonable level. ${ }^{11},{ }^{13}$ Because of this issue, if there are many variables, the number of decision-making units also increases. But this situation disrupts a homogeneity problem. ${ }^{15}$

\section{Methodology}

The selection of input and output variables has a great importance, especially for the health sector. In general, for health services it is very difficult to find appropriate variables ${ }^{25}$, to obtain accurate input and output data and to access reliable databases where have uniform definitions of input and output. For this reason, the aim of this study is to determine what input, output variables and decision-making units are used in studies, which efficiencies of healthcare is assessed by DEA; and what input and output variables used in the last few years are.

In this study, firstly researches in the health care literature evaluated efficiency by DEA have been determined. The literature has been thoroughly reviewed and it has seen that data envelopment analysis has been used in a wide range of studies in healthcare. In order to narrow the numbers of these studies and to obtain up-to-date information, it has been decided to examine those studies involving a seven-year period. Therefore, studies conducted by using DEA in health care between 2010 and October 2017have been examined.

Databases such as Google Scholar, Ebscohost, Institutions of Higher Education Database in Turkey were scanned to reach all of the studies that measure health care efficiency using data envelopment analysis. Afterwards, some eliminations were made according to the criteria determined by the author. The criteria set by the author are as follows: 
$\checkmark$ Using data enveloping analysis in applications for health care,

$\checkmark$ To include research article, not review article,

$\checkmark$ Using Turkey, the presence of Turkey or health institutions operating in Turkey as decision-making units,

$\checkmark$ To access the full text of research,

$\checkmark$ The publication of the studies between 2010 and 2017,

$\checkmark$ Published in English and Turkish languages,

$\checkmark$ To find "efficiency", "efficiency analysis" or "data envelopment analysis" statements in the title of the study

Publications matching these criteria have been evaluated within the scope of the study. A total of 52 publications fulfilled the inclusion criteria. These researches were examined according to the publication year, type of the research, input variables, output variables and decision-making units used by these publications.

As a result of the findings, numerical and percentage data about input, output variables and decision-making units of publications matching the criteria are shown with graphs and tables.

\section{Results}

Within the scope of the study, there are 52publications (see the Appendix) published in seven years period between 2010-2017. The distribution of these publicationsby years is given in Figure 1.

\section{Figure 1}

In Turkey, DEAwas frequently used in 2010 to analyze efficiency of healthcare service. In 2011, the numbers of the studies used in DEA decreased suddenly and in this year there are only six studies in terms of the criteria. Although there are increased interest to apply DEA after 2011, it has not reached the level of 2010 again (Figure 1). 


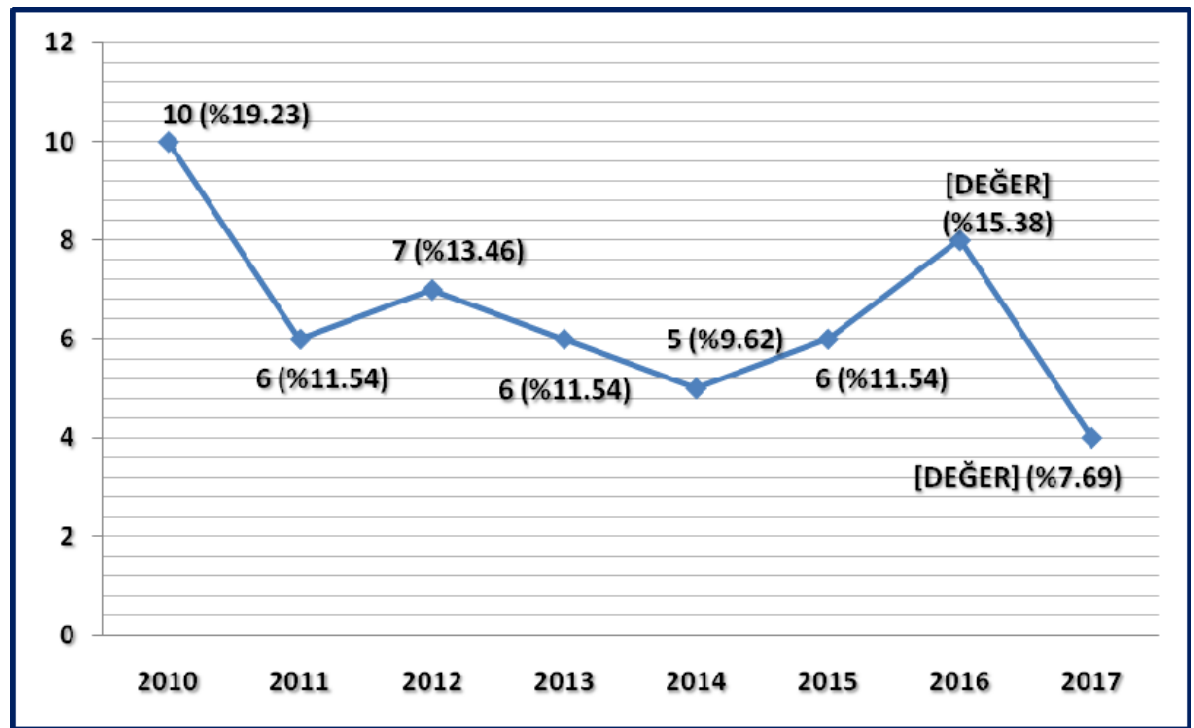

Figure 1. Number of DEA Publications by Years

The distribution of types of publications by years are presented in Figure 2.

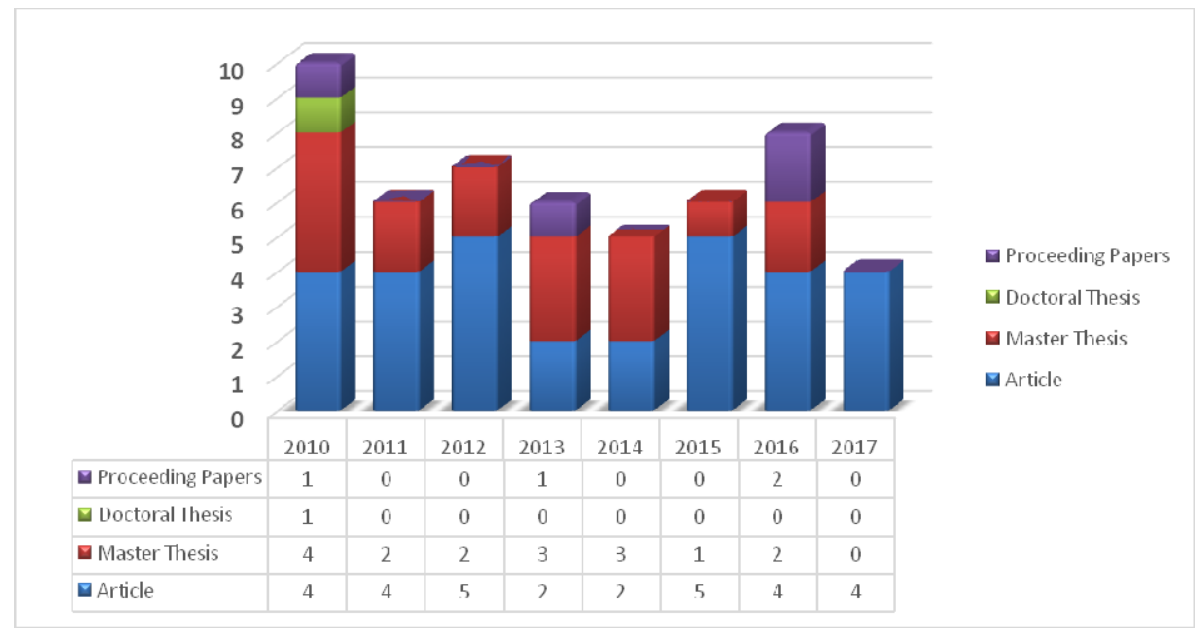

Figure 2. Distribution of Types of Publications by Years 
It has been determined that publications are only published as articles in 2017. In 2011, 2012, 2014 and 2015 also master thesis have been published out of articles. In terms of the types of studies, the greatest diversity is seenin 2010.Unlike other years, one doctoral thesis and one proceeding paper also have been published in 2010 (Figure 2).

Table 1 provides an overview about different DMUs used in publications.

Table 1. Decision-Making Units of DEA Applications

\begin{tabular}{lcc}
\hline Decision Making Units & $\boldsymbol{n}$ & $\boldsymbol{\%}$ \\
\hline Hospital & 32 & 61.54 \\
Family Medicine Units & 4 & 7.69 \\
OECD Countries & 3 & 5.77 \\
Physicians / Family Physicians & 3 & 5.77 \\
Nomenclature of Territorial Units for Statistics in Turkey & 2 & 3.85 \\
Oral and Dental Health Center & 2 & 3.85 \\
Public Hospitals Association & 2 & 3.85 \\
Organ Transplant Center & 1 & 1.92 \\
Provinces of Turkey & 1 & 1.92 \\
Turkey and The Balkan Countries & 1 & 1.92 \\
G-20 Countries & 1 & 1.92 \\
\hline Total & $\mathbf{5 2}$ & $\mathbf{1 0 0 . 0 0}$ \\
\hline
\end{tabular}

In a large number of studies, hospitals has also been used as DMUs. More than half of the 52 study (61.54\%) selected hospitals as decision-making units. Out of the hospital, $7.69 \%$ of the studies used the Family Medicine Unit, $5.77 \%$ of them used the OECD countries and physicians/family physicians, $3.85 \%$ of the studies evaluated the efficiency of Nomenclature of Territorial Units for Statistics in Turkey, Oral and Dental Health Center and Public Hospitals Associationas DMUs (Table 1).

Different input and output variables are used to analyze the efficiency of different decision making units. In this study, it was determined which input and output variables was used frequently in the publications. But, DEA is a data-driven method and the results are sensitive to selection of these variables. For this reason, in order to provide homogeneity, information about the most commonly used input and output variables to evaluate the efficiency of hospitals was 
presented in this paper. Because hospital is used commonly (61.54 $\%)$ as a DMUs in publications.

Information about input variables used in the thirty two publications that selected the hospital as a decision-making unit is given in Figure 3.

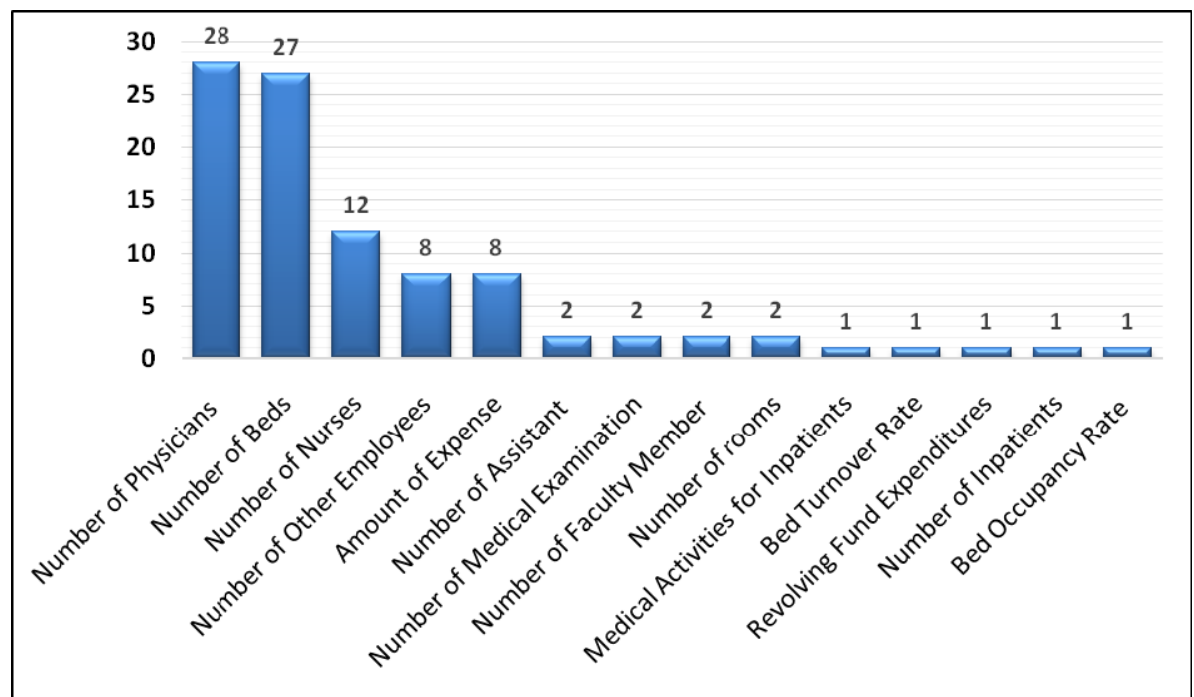

Figure 3. Input Variables Used in Publications That Selected The Hospital as a DMU

*Since more than one input variable is used in the same study, the sum of the numbers is more than 52

"Number of phyisicians" was used in 28times and "number of beds" was used in 27times as an input variable in the studies which decision-making unit was a hospital.In addition to these two input variables, "number of nurses", "number of other employees" and "amount of expense" are often used in the studies (Figure 3). While some of the studies using the number of physicians as an input variable refered to the total number of physicians; some of them used a number of specialist physicians, general practitioners, and assistant physiciansseparately as an input variable. However in this study, there was no distinction of physician type.

Information about the output variables used in the thirty two studies that selected the hospital as a decision-making unit is given in Figure 4. 


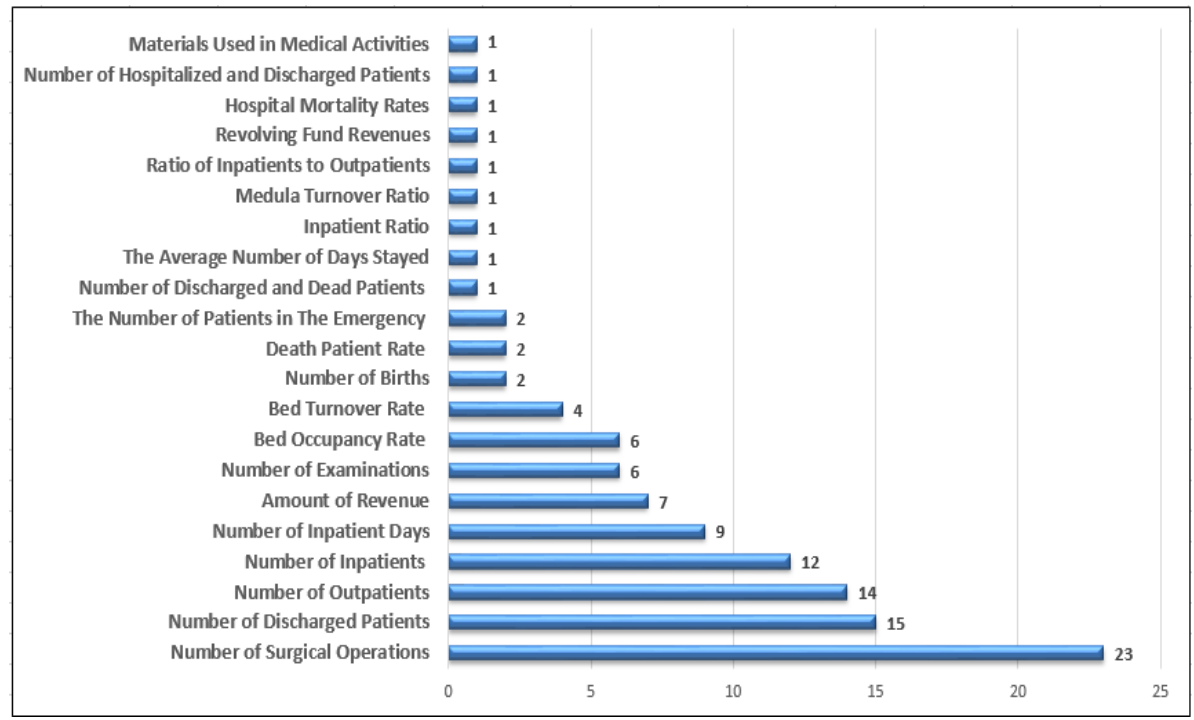

Figure 4. Output Variables Frequently Used in Researches Using the Hospital as a Decision-Making Unit

*Since more than one input variable is used in the same study, the sum of the numbers is more than 52

"The number of surgical operations" was used as an output variable in 23 times and "Thenumber of discharged patients" was used as an output variable in 15times in the studies which decisionmaking unit was a hospital. Out of these two variables, other output variables that are frequently used are "number of outpatients, number of inpatient" and "number of inpatient days" (Figure 4).

The list of 52selected publications selected according to the criteria are in Appendix.

\section{Conclusion And Recomendations}

In recent years, limitation of resourcesin health services, which is an important issue for individuals and community life, the continuous increase in health expenditures, changes in disease structure, innovations in medical science and technology and also competition among service providers require health services to be delivered effectively and efficiently. For this reason, the businesses continuously measure their efficiency. 
Data envelopment analysis (DEA) is one of the widely used efficiency measuring method in the literature. But, there is no common DEA model to meet needs of all businesses. Each Businesses chooses the appropriate input and output variables according to their structure. Selection of input or output variables is an important issue that varies depending on what you want to see as an output, which inputs or environmental factors are more likely to affect this output ${ }^{26}$.Therefore, the input and output variables used to compare the relative efficiencies of decision-making units are selected with great care and accuracy. ${ }^{27,} 28$ Moreover, in order to measure health outcomes, the appropriate analytical method which combines the possible number of inputs and outputs should be defined. ${ }^{29}$

Data envelopment analysis is also often used for efficiency measurement in health care. The selection of input and output variables is also very importantfor the health sector. In general, it is very difficult to find appropriate variables according to the nature of health services ${ }^{25}$, to obtain accurate input and output data and to access reliable databases where uniform definitions for input and output variables related to the healthcare are involved in.

Because of the absence of a standard input-output set in health care, there are different inputs and outputs in the literature. This is a distressing and complicated situation for researchers who want to measure efficiency using data envelopment analysis. This study is designed to resolve this complexity, to give information about the most frequently used input and output variables and be able to help to the researchers, academics and health economics.

In this study, there are 52 studies that meet the criteria set created by the author. In Turkey, DEA was frequently used in 2010 to analyze efficiency of healthcare service. Researches are published as only articles in 2017. In 2011, 2012, 2014 and 2015, master thesis has also been worked out of the articles. The greatest diversity in terms of types of the studies is in 2010.Unlike other years, one doctoral thesis and one proceeding paper also were published in 2010.

More than half of the 52 studies (approx. $62 \%$ ) selected hospital as a decision-making unit. In this study, since the most used decisionmaking unit was the hospital, information about the most commonly used input and output variables of publications evaluated the efficiency of hospitals was presented.It is thought that the homogeneity will be provided in the compilation of the data. Input and output variables that are frequently used in top five of researchesevaluated the hospitalefficiencyare given in Figure 5. 


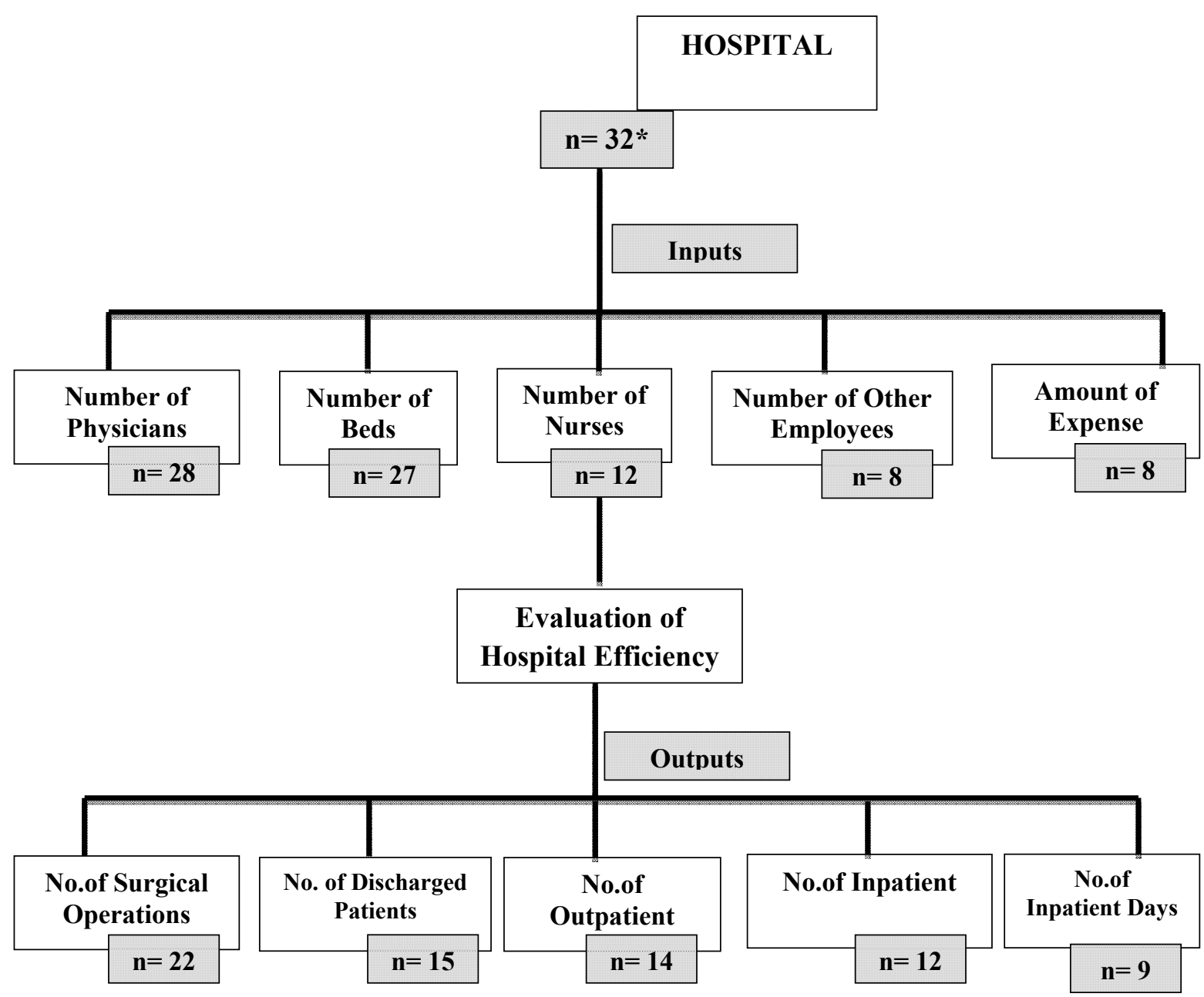

Figure 5. The Summary ofInput and Output Variables of Publications Evaluated The Hospital Efficiency *Several input and output variables have been used in more than one studies 
It is very important that health manpower must be sufficient in terms of quality and quantity for assessing the efficiency of hospitals. In this study, the most frequently used input variable was identified as "the number of physicians". This input variable is followed by "the number of beds", "the number of nurses", "the number of other employees" and "amount of expense" respectively. Input variables that are frequently used in top five of 32 studies whose decisionmaking unit was a hospital can be collected under three groups (labor, beds, expense).Similarly, O'Neill et al. (2008) collect hospital input variables under three broad sub-categories (capital investment, labor and other operating expense). ${ }^{20}$ When foreign literature is examined except for the publications made in Turkey, similar findings are optained with this study.In international publications, the number of physicians, number of nurses, number of beds, number of other personnel, total amount of expense were used as input variables in evaluation of hospital efficiency. ${ }^{30-33}$

In the study, the most frequently used output variable was "the number of surgical operations". This output variable is followed by "the number of discharged patients","the number of outpatients", "the number of inpatient", "the number of inpatient days" respectively. O'Neill et al. (2008) identified hospital oputput variables into four subcategories: (1) "medical visits, cases, patients and surgeries"; (2) "inpatient days"; (3) "admissions, discharges and services"; (4) "atypical, teaching and specific output categories" ${ }^{20}$.Findings in this study are also compatible with these four categories. It can be said that the output variables used in the studies are more diversified than input variables.

As a result, the aim of this study isto determine commonly used decision making units, input and output variables in health carein Turkey through a systematic review. This study will provide important information about understanding the strengths, gaps and limitations of evaluating the health efficiencies and assist to hospital managers, policy makers, researchers, academics and health economics. With this study, also it will be contributed to the literature and future studies to be conducted on healthcare efficiency.

For future researches, it is recommended to fill the gaps in selection of input and output variables, to integrate the using of the other relevant input and output factors such as environmental variables like socio-economic and lifestyle factors. Varabyova and Müller (2016) considered education, income, unemployment, income 
inequality and age structure as an socio-economic factors; tobacco consumptions, alcohol consumptions, dietary choice and pullution as an lifestyle factors. ${ }^{34}$ All of these factors are related to health, whether directly or indirectly. Because, health is not a single concept, it isa multidimensional notion.

\section{Compliance With Ethical Standards}

Conflict of interests Author declares that she has no conflict of interest.

Funding There has no funding

Ethical approval This article does not contain any studies with human participants or animals performed by the author.

\section{REFERENCES}

1. Akyuz, K.C, Yıldırım,I, Balaban, Y. Measuring efficiencies of the firms in paper sector by using data envelopment analysis. International Journal of Economic and Administrative Studies 2015;14: 23-38.

2. Kok, R.Endüstriyel verimlilik ve etkinlik - bir uygulama. Erzurum: Ataturk Universitesi Yayınları, Yayın No: 680, Iktisadi ve Idari Bilimler Fakultesi Yayın No: 90, Arastırma Serisi No: 81, 1991.

3. Kula, V, Ozdemir, L.Cimento sektöründe göreceli etkinsizlik alanlarının veri zarflama analizi yöntemi ile tespiti. Afyon Kocatepe Universitesi Iktisadi ve Idari Bilimler Fakultesi Dergisi 2007;IX(1): 55-70 2007.

4. Ozturk, Y.E,A research on the efficiency rise of the university hospitals in the Turkish health sector based on data envelopment analysis. Dissertation, Selcuk University, 2009.

5. Kalirajan, K.P, Shand, R.T.Frontier production functions and technical efficiency measures. Journal of Economic Surveys 1999;13(2): 149172.

6. Safak, I.: Assessment of efficiency levels of forest enterprises in the Aegean region. Dissertation, Celal Bayar University, 2009.

7. Ulucan, A.:Yoneylem arastırması - isletmecilik uygulamaları bilgisayar destekli modelleme.Ankara:Siyasal Kitabevi, 2007.

8. Moreno, L, Aguilar, R.M, Martin, C.A, Pineiro, J.D, Estevez, J.I, Sigut, J.F, Sanchez, J.L, Jimenez, V.I.Patient-centered simulation tool for aiding in hospital management. Simulation Practice and Theory, 1999; 7: 373-393. 
9. Boussofiane, A., Dyson, R.G., Thanassoulis, E.:Applied data envelopment analysis. European Journal of Operational Research, 1991;52, 1-15.

10. Li, Y, Liang, L, Chen, Y, Morita, H.Models for measuring and benchmarking olympics achievements. Omega, 2008;36, 933-940.

11. Ramanathan, R.An introduction to data envelopment analysis a tool for performance measurement. New Delhi:Sage Publications,2003.

12. Wei, Q. Data envelopment analysis. Chinese Science Bulletin,46(16),13211332.http://www.springerlink.com/content/d21w3x3883v56j0v/(2001). Accessed 10 April 2016

13. Tutek, H.H, Gumusoglu. S, Ozdemir, A.Sayısal yontemler - yonetsel yaklasım. Istanbul: Beta Yayınları, 2012.

14. Cook, W.D. Seiford, L.M. Data envelopment analysis (DEA) - thirty years on. European Journal of Operational Research, 2009;192, 1-17.

15. Yolalan, R, Isletmelerarası goreli etkinlik olcumu. Ankara, Milli Produktivite Merkezi Yayınları, Yayın No: 483, 1993.

16. Aydemir, Z.C.Bolgesel rekabet edebilirlik kapsamında illerin kaynak kullanım gorece verimlilikleri: veri zarflama analizi uygulaması. Devlet Planlama Teskilatı Uzmanlık Tezi. Yayın No: DPT: 2664, 2002

17. Charnes, A, Cooper, W.W, Lewin, A.Y, Seiford, L.M. Data envelopment analysis, theory, methodology and applications. Kluwer Academic Publishers.http://deazone.com/en/googlebook-orzz-kkc2mwc(1994). Accessed20 April 2016

18. Cellini, R, Pignataro, G, Rizzo, I.Competition and efficiency in health care: an analysis of the Italian case. International Tax and Public Finance 2000;7: 503-519.

19. Chilingerian, J.A, Sherman, H.D.Health-care applications: from hospitals to physicians, from productive efficiency to quality frontiers. In: Cooper, W.W, Seiford, L. M, Zhu, J. (eds.) Handbook on Data Envelopment Analysis, pp. 445-493. London: Springer, 2011.

20. O'Neill, L, Rauner, M, Heidenberger, K, Kraus, M. A cross-national comparison and taxonomy of DEA-based hospital efficiency studies. Socio-Economic Planning Sciences 2008;42(3): 158-189.

21. Pelone, F, Kringos, D.S, Romaniello, A, Archibugi, M, Salsiri, C, Ricciardi, W.Primary care efficiency measurement using data envelopment analysis: a systematic review. Journal of Medical Systems2015;39(1): 1-14.

22. Ayrıcay, Y, Ozcalıcı, M.Academic studies that used data envelopment analysis and published in Turkey between 1997-2012. Kahramanmaras 
Sutculmam University Faculty of Economics and Administrative Sciences Journal,2014;4(1): 245-278.

23. Deniz, N. Determining relative efficiency of Turkish provinces according to their resource utilization by classic and fuzzy data envelopment analysis methods. Dissertation: Anadolu University, 2009.

24. Kecek, G.Veri zarflama analizi teori ve uygulama örneği. Ankara: Siyasal Kitabevi, 2010.

25. Ozcan, Y.A.Healthcare benchmarking and performance evaluation an assessment using data envelopment analysis (DEA). USA: Springer, 2008.

26. Champaner, E.I.Evaluating relative productivity and efficiency of hospitality properties using data envelopment analysis. Dissertation, University of Nevada, 2003.

27. Akyuz, K.C,Camur, G, Yıldırım,I.Activity analysis with data envelopment analysis in the furniture and panelboard sectors. Turkish Journal of Forestry 2015;16(1): 50-59.

28. Griffin, P.M, Kvam, P.H.A quantile-based approach for relative efficiency measurement. Managerial and Decision Economics 1999;20: 403-410.

29. Hadad, S, Hadad, Y, Simon-Tuval, T. Determinants of healthcare system's efficiency in OECD countries. European Journal of Health Economics 2013; 14: 253-265.

30. Alamin, T.H.M, Yassin, A.A.Measuring hospitals efficiency using data envelopment analysis tool: study on governmental hospitals services at Ministry of Health-Khartoum State 2012. International Journal of Science and Research2015;4(2): 1586-1592.

31. Alonso, J.M, Clifton, J, Diaz-Fuentes, D.The impact of new public management on efficiency: an analysis of Madrid's hospitals. Health Policy 2015;119: 333-340.

32. Du, J, Wang, J, Chen, Y, Chou, S.Y, Zhu, J. Incorporating health outcomes in Pennsylvania Hospital efficiency: an additive superefficiency DEA approach. Annals of Operations Research 2014; 221:161-172.

33. Chuang, C.L, Chang, P.C, Lin, R.H.An efficiency data envelopment analysis model reinforced by classification and regression tree for hospital performance evaluation. Journal of Medical Systems 2011;35: 1075-1083.

34. Varabyova, Y, Müller, J.M. The efficiency of health care production in OECD countries: A systematic review and meta-analysis of crosscountry comparisons. Health Policy 2016; 120: 252-263. 


\section{APPENDIX. SELECTED ARTICLE}

[SA1] Aksoy I.The comparison of health efficiency of the countries with classic and fuzzy data envelopment analysis and an investigation of an alternative approach to create fuzzy data. Dissertation, Muğla Sıtkı Koçman University 2014.

[SA2]Arancı A. Veri zarflama analizi yöntemi ile Kars Devlet Hastanesi polikliniklerinin performans değerlendirmesi. Yüksek Lisans Tezi. Kafkas Üniversitesi 2012.

[SA3] Atmaca E, Turan F, Kartal G, Çiğdem, E.S. Efficiency measurement using data envelopment analysis in Ankara private hospitals. Journal of Cukurova University Faculty of Economics and Administrative Sciences 2012; 16(2): 135-153.

[SA4]Ayanoglu Y, Atan M, Beylik U. Assessments and measurement of financial performance using the methodology of data envelopment analysis (DEA) in hospitals. Saglıkta Performans ve Kalite Dergisi2010;2:40-62.

[SA5]Aytekin S.The performance measurement of the health hospitals with low bed occupancy rates: an application of data envelopment analysis. Uludag Journal of Economy and Society 2011;XXX (1): 113-138.

[SA6]Bal V.Measurement of the effects of information systems on the performance of health institutions through data envelopment analysis; a research on state hospitals in Turkey. Dissertation, Suleyman DemirelUniversity, 2010.

[SA7]Bal V.Data envelopment analysis and medical image archiving and communication systems to investigate the effects of the performance of public hospitals. Journal of Suleyman Demirel University Institute of Social Sciences2013;17: 31-50.

[SA8]Bal $V$, Bilge $H$. Efficiency measurement with data envelopment analysis in education and research hospitals. Manas Journal of Social Studies 2013;2(2): 1-14.

[SA9]Bakırer A. 663 sayılı KHK'nin devlet hastanelerinin verimliliklerine olan etkisinin veri zarflama analizi ile ölçümü. Yüksek Lisans Tezi, Cumhuriyet Üniversitesi 2016.

[SA10]Bayraktutan Y, Arslan I, Bal V.The evaluation of the effects of health information systems to the performance of hospitals by data enveloping analysis: an application in the thoracic medicine hospitals. Gaziantep Medical Journal 2010;16(3): 13-18. 
[SA11]Bayraktutan $Y$, Pehlivanoglu P. An efficiency analysis in health businesses: the caseof Kocaeli. Kocaeli University Journal of Social Sciences 2012;23: 127 - 162.

[SA12]Beylik U,Ayanoğlu Pekcan Y.Assessments of analysis efficiency in training and research hospitals.Saglıkta Performans ve Kalite Dergisi2012;3:119-156.

[SA13] Beylik U, Kayral I.H, Naldöken, Ü. Public hospital unions performance analysis in terms of health care services efficiency. Cumhuriyet University The Journal of Social Sciences 2015; 39(2): 203224.

[SA14] Bircan H. Meausrement of the efficiency of village clinics in the Sivas by data envelopmentAnalysis. Cumhuriyet University Journal of Economics and Administrative Sciences 2011; 12(1): 331-347.

[SA15] Çalışkan S, Girginer N. Evaluation of the Performance of Hospitals in Turkey with Data Envelopment Analysis. EconWorld2016@ImperialCollege Proceedings 10-12 August 2016; London-England, 1-11.

[SA16] Çelebi A.K, Cura S. Efficiency of Public Health Expenditure: Turkey and The Balkan Countries. 2nd International Congress on Economics and Business 30 May-3 June 2016; Sarajevo - Bosnia and Herzegovina, 1138-1147.

[SA17] Celik T, Esmeray A. Measurement of cost effıciency in private hospitals in Kayseri using by data envelopment analysis. International Journal of Alanya Faculty of Business 2014; 6(2): 45-54.

[SA18] Doğan N.Ö. Measuring the efficiency of primary healthcare organizations in the Cappadocia Region using data envelopment analysis.11th International Conference of DEA June 2013; SamsunTurkey, 263-269.

[SA19]Dogan N.O, Gencan S. Performance assessment using DEA/AHP integrated method: an application on public hospitals in Ankara.Gazi Universitesi Iktisadi ve Idari Bilimler Fakultesi Dergisi 2014;16(2): 88112.

[SA20] Erinç M.S. Study on a performance assessment of family physicians in a province with data envelopment analysis. Dissertation, Hacettepe University 2013.

[SA21]Ertürk Akdal S.Health institutions and regional event performance management and data analysis application technique envelopment analysis. Dissertation, Beykent University 2013. 
[SA22] Girginer N, Kose T,Uckun N. Efficiency analysis of surgical services by combined use of data envelopment analysis and gray relational analysis. Journal of Medical Systems2015; 39(5): 1-9

[SA23]Gok M.S, Sezen B. Analyzing the efficiencies of hospitals: an application of data envelopment analysis. Journal of Global Strategic Management2011;10: 137-146.

[SA24]Güler M. Data envelopment analysis performance by health agencies andan application. Dissertation, Dokuz Eylül University 2014.

[SA25] Gülsevin G, Türkan A.H. Evaluation of efficiencies of hospitals in Afyonkarahisar using data envelopment analysis. Afyon Kocatepe University Journal of Sciences 2012; 1-8.

[SA26] Irmak E.D. Determination of technical efficiency of Sivas Public Hospitals by using data envelopment analysis. Dissertation, Cumhuriyet University 2014.

[SA27]Kar A, Şantaş F, Kahraman G, Gürvardar Y. Technical efficiency of Gynecology and Obstetrics Hospitals In Turkey: measurement by data envelopment analysis. The Journal of Academic Social Science 2016; 4(34): 372-382.

[SA28]Kocaman A.M, Mutlu M, Bayraktar D, Araz Ö.M.Health care system efficiency analysis of OECD countries. Endustri Muhendisligi Dergisi2012;23(4): 14-31.

[SA29]Levent P.The comparative efficiency and productivity analysis of public and university hospitals in Izmir (an application of data envelopment analysis). Dissertation, Ege University, 2010.

[SA30]Narcı H.O, Ozcan Y.A, Sahin I, Tarcan M, Narcı M. An examination of competition and efficiency for hospital industry in Turkey. Health Care Management Science 2015; 18:407-418.

[SA31]Okursoy A, Ozdemir, M. Cluster analysis approach for a nonhomogeneous DMU's problem in DEA. Ege Academıc Review 2015;15(1): 81-90.

[SA32]Olcek Buzkıran B.Performance comparisons of organ transplantation centers in Turkey with data envelopment analysis. Dissertation, Akdeniz University, 2012.

[SA33]Oner N.The assesment of performance of oral and dental health institutions subordinate to Ministry of Health with the method of data envelopment analysis. Dissertation, Gazi University, 2010.

[SA34]Ozata M, Sevinc I.Konya'daki saglık ocaklarının etkinlik duzeylerinin veri zarflama analizi yontemiyle degerlendirilmesi. Ataturk Universitesi Iktisadi ve Idari Bilimler Dergisi2010;24(1): 77-87. 
[SA35] Öztürk E.G. Health system performance in OECD countries: data envelopment analysis. Hacettepe University Institute of Social Sciences 2016; Ankara.

[SA36]Ozdemir Y.Measuring Relative Technical Effectiveness of Republic of Turkey Ministry of Health Mouth and Dental Health Care Centers by means of Data Envelopment Analysis. Dissertation, Hacettepe University, 2011.

[SA37]Pakdil F, Akgul S, Doruk T.C, Kececi B.Kurumsal performans yonetiminde veri zarflama analizi sonuclarının kullanımı: universite hastaneleri karsılastırması. II. Uluslararası Saglıkta Performans ve Kalite Kongresi.Ankara, 2010, 133-143.

[SA38]Sarı Z. Data envelopment analysis and an application. Dissertation, Hacettepe University 2015.

[SA39]Sarıkaya M. Evaluation of health activities in the provinces in Turkey (data envelopment analysis based application). Dissertation, Gazi University, 2010.

[SA40]Sebetci Ö, Uysal İ. The Efficiency of Clinical Departments in Medical Faculty Hospitals: A Case Study Based on Data Envelopment Analysis. International Journal of Computer Sciences and Engineering 2017;5(7): 1-8.

[SA41] Sevimli O. The productivity analysis with data envelopment analysis method in medical institutions. Dissertation, Beykent University, 2013.

[SA42] Sülkü S.N. The effects of performance based supplementary payment system on the efficiency of Public Hospitals. Maliye Dergisi 2011; 160: 242-268.

[SA43] Şener M, Yiğit V. Technical Efficiency of Health Systems: A Research On The OECD Countries. Journal of Süleyman Demirel University Institute of Social Sciences 2017; 26: 266-290.

[SA44] Taşlıdere S, Saraçoğlu G.V, Topçu, B. To determine the performance of family physicians working in a district of Tekirdağ using data envelopment analysis. Namık Kemal Medical Journal 2017; 5(2): 75-82.

[SA45]Temür Y.Illeringelismislik derecelerine gore hastanelerin etkinlik analizi. Uludag Journal of Economy and Society 2010;XXIX(2): 1-22.

[SA46] Uçkun N, Girginer N, Köse T, Şahin Ü. Analysis efficiency of public hospitals of metropolitan municipalities in Turkey. International Journal of Innovative Research in Education 2016; 3(2): 102-108.

[SA47] Uyar M, Sahin T.K. Evaluation of Efficiency of Primary Health Cares in Konya City Centre. TAF Preventive Medicine Bulletin2015; 14(1):1-6. 
[SA48] Yiğit V. Technical Efficiency Analysis in Hospitals: An Application of Public Hospitals Association. Suleyman Demirel University Journal of Health Sciences 2016; 7(2): 9-16.

[SA49] Yiğit V. Technical Efficiency of Physicians In Performance Based Supplementary Payment System: Application In A University Hospital. Electronic Journal of Social Sciences 2017; 16(62): 854-866.

[SA50] Yiğit V. Technical Efficiency Analysis of Medical Department of A University Hospital. Journal of Süleyman Demirel University Institute of Social Sciences 2016; 23: 199-214.

[SA51]Yoluk M.Evaluation of hospital performance using the methodology of data envelopment analysis. Dissertation, Atılım University, 2010.

[SA52]Zengin S. Measurement and evaluation of hospital efficiency by data envelopment analysis. Marmara University Institute For Graduate Studies In Pure and Applied Sciences 2011; Istanbul. 
